\title{
Effect of Plasma Exposure Time on the Polyphenolic Profile and Antioxidant Activity of Fresh-Cut Apples
}

\author{
Silvia Tappi ${ }^{1, *}$, Ileana Ramazzina ${ }^{2}\left(\mathbb{D}\right.$, Federica Rizzi ${ }^{2}$, Giampiero Sacchetti ${ }^{3}$, Luigi Ragni ${ }^{1,4}$ and \\ Pietro Rocculi ${ }^{1,4}$ \\ 1 Inter-Departmental Centre for Agri-Food Industrial Research, University of Bologna, via Quinto Bucci 336, \\ 47521 Cesena (FC), Italy; luigi.ragni@unibo.it (L.R.); pietro.rocculi3@unibo.it (P.R.) \\ 2 Department of Medicine and Surgery, University of Parma, via A. Gramsci 14, 43126 Parma (PR), Italy; \\ ileana.ramazzina@unipr.it (I.R.); federicamariaangel.rizzi@unipr.it (F.R.) \\ 3 Faculty of Bioscience and Technology for Agriculture, Food and Environment, University of Teramo, \\ Campus Coste S. Agostino, Via Balzarini 1, 64100 Teramo, Italy; gsacchetti@unite.it \\ 4 Department of Agricultural and Food Sciences, Università di Bologna, P.zza Goidanich 60, \\ 47521 Cesena (FC), Italy \\ * Correspondence: silvia.tappi2@unibo.it; Tel.: +39-0547-338103
}

Received: 30 September 2018; Accepted: 13 October 2018; Published: 16 October 2018

Featured Application: The application of cold plasma to agricultural products has recently drawn considerable attention as a technology for microbial decontamination and product stabilization. However, for an industrial application, it is fundamental to understand its effect on quality and nutritional value. This study is a contribution to the increased knowledge on this issue.

\begin{abstract}
Cold atmospheric plasma (CAP) has shown good potentiality for the decontamination and stabilization of fresh fruit and vegetable products; however, information about its effect on nutritional quality is still scarce. The aim of this research was to evaluate the impact of a form of indirect treatment known as Dielectric Barrier Discharge (DBD) on apple slices-more specifically, the polyphenolic profile and antioxidant activity of fresh-cut Pink Lady apples. Atmospheric plasma was generated using air as feed gas, and directed to apple slices for up to $30 \mathrm{~min}$. The effect of plasma treatment on physico-chemical parameters was mainly observed as a slight acidification of the tissue and reduction of browning after an extended period of exposure. The samples' phenolic profile was significantly affected after $10 \mathrm{~min}$ of treatment, both in quantitative (an approximately $20 \%$ increase) and qualitative terms, while with increasing exposure time a progressive decrease of all polyphenol classes was observed. The antioxidant activity, evaluated by different in-vitro methods, followed a similar trend, increasing after $10 \mathrm{~min}$ of processing and then decreasing. Results highlighted how plasma exposure promotes a metabolic response of the fresh tissue, and the importance of carefully controlling the exposure time in order to minimize the loss of nutritional properties.
\end{abstract}

Keywords: fresh-cut apples; cold plasma; polyphenols content; antioxidant activity

\section{Introduction}

Cold atmospheric plasma (CAP), which, in the past, has mainly been used in the medical field [1,2], has recently drawn considerable attention as a novel non-thermal technology for food product decontamination [3]. Besides the non-thermal nature of plasma, additional positive features of this technology rely on the fact that it is a dry technology, environmentally friendly, and, in most cases, represents a cost-efficient solution that can supplement or replace other technologies.

CAP has shown promising results in terms of decontamination of various microorganisms [4], molds, and mycotoxins [5], and for its potential to inactivate viruses [4] in food products. Another 
important application of CAP in foods is the partial inactivation of food enzymes that may have positive effects on products' shelf-life [6].

Despite the high potentiality, there are still many aspects about CAP technology that need to be addressed. Firstly, there are currently some practical limitations for the scaling-up of the equipment, starting from the standardization of plasma analytical techniques, safety measures for operators and the environment, to the design of equipment which are able to process large amounts of product in a continuous way [7].

Moreover, there are still aspects-particularly regarding food quality, functional characteristics, and potential toxicity of treated products-that are unknown or that need clarification. The European Food Safety Authority (EFSA) requires a scientific assessment to be done prior to authorization to ensure the novel technologies' safety. Currently, uncertainty remains in the European Commission's (EC) regulatory approval process for CAP technologies due to the lack of scientific data and ambiguous statements within the evaluation criteria (e.g., "risk to public health", "nutritionally disadvantageous", and "not misleading to the consumer").

With regard to the nutritional properties, few studies have investigated the CAP's effect on bioactive compounds of fruit and vegetable products.

Grzegorzewski et al. [8-10] observed a partial oxidation of phenolic components in green leafy vegetables, although mitigation by the matrix effect compared to treatment of pure components was found. On the other hand, only a slight decrease in the total phenolic content and antioxidant activity of apple slices was observed [11]. Vitamin C was found to be only slightly affected by plasma exposure in kiwifruit [12] and various vegetable slices [13]. Thus, it appears that the degradation of bioactive components is strictly dependent on the matrix.

However, studying the effect of direct plasma treatment on fruit juice (chokeberry, sour cherry, and pomegranate) using a plasma jet device with pure Argon, an increase of specific classes of polyphenols (anthocyanins and phenolic acids) was found at the shortest treatment time (3 to $4 \mathrm{~min}$ ) [14-16].

According to these authors, the observed increase was caused by increased extractability due to disruption of the cell membrane's integrity, promoted by plasma-reactive species.

The increase of secondary metabolites, such as flavonol glycosides in plant tissue was also observed by BuBler et al. [17] after the exposure of pea seedlings to plasma. This result was attributed to a response mechanism of the tissue in terms of photosynthetic activity, and of the response metabolism against oxidative stress due to UV exposure.

In a previous study [11], we demonstrated that a $15+15$ min treatment caused only a slight reduction of polyphenols content and antioxidant activity on fresh-cut apples, which did not seem to interfere with the physiological responses for moderating the oxidative stress of cells loaded with the plasma-treated apple extracts. The reduction of phenolic content was probably due to oxidation promoted by plasma-active particles and radicals; nevertheless, the response of living tissue to plasma exposure may be more complex and dependent on treatment time.

In the present study, we investigated how plasma exposure time, from 10 to $120 \mathrm{~min}$, affected the phenolic profile and antioxidant activity of fresh-cut apples.

\section{Materials and Methods}

\subsection{Raw Material Handling and Storage}

Apples (Malus domestica cv. 'Pink Lady ${ }^{\circledR \prime}$ ') harvested two weeks before transportation were provided by the local market. Fruits free from defects were transported to our laboratory and stored in a refrigerated chamber at $5 \pm 1{ }^{\circ} \mathrm{C}$ and a saturated atmosphere in darkness for one week. Apples

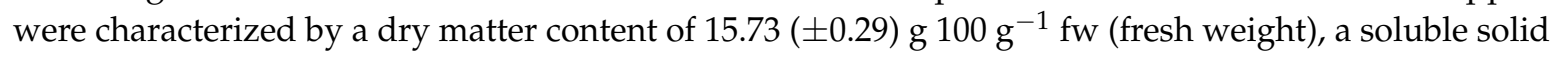
content of $14.27( \pm 0.35)^{\circ}$ Brix, and a titrable acidity of $0.39( \pm 0.03) \mathrm{mg}$ malic acid $\mathrm{g}^{-1} \mathrm{fw}$. 


\subsection{DBD Gas Plasma Generator and Treatments}

Cold plasma was generated by a Dielectric Barrier Discharge (DBD) device that had been previously described and characterized by Ragni et al. [18]. It consists of a hermetic chamber containing three parallel pairs of electrodes (brass) supplied by a DC power supply and powered by high-voltage transformers and power-switching transistors. A $5 \mathrm{~mm}$ thick glass was used as dielectric material. As feed gas, atmospheric air driven at $1.5 \mathrm{slm}$ was chosen. The frequency of oscillation was $12.7 \mathrm{kHz}$, and the supply power was in the range of $150 \mathrm{~W}$.

The discharge was characterized by emission spectroscopy in previous studies [16] that showed the presence of oxygen and nitrogen radicals and ions as commonly detected when atmospheric air was used to generate plasma.

\subsection{Sample Preparation and Plasma Treatments}

Apple slices (dimension: $40 \times 10 \times 10 \mathrm{~mm}$, weight: $11.08 \pm 1.21 \mathrm{~g}$ ) were manually obtained from apple flesh using a sharp blade. For each treatment time, 15 slices were used. Samples were exposed to cold plasma at a distance of $70 \mathrm{~mm}$ from the electrodes for a total of 10 ( $5+5$ on each side), $20(10+10$ on each side), and $30(15+15$ on each side $) \mathrm{min}$. In the treatment chamber, the temperature was $22{ }^{\circ} \mathrm{C}$ and relative humidity (RH) was $60 \%$.

Treatment time was elongated to $120(60+60)$ min of processing, only for polyphenols and in vitro antioxidant activity determinations.

\subsection{Physico-Chemical Parameters}

Water content was obtained gravimetrically on about $5 \mathrm{~g}$ of finely chopped apples precisely weighted, after drying at $70{ }^{\circ} \mathrm{C}$ until it achieved a constant weight [19]. Soluble solid content (SSC) was measured with the juice obtained from apple slices after being filtered through Whatman \#1 filter paper with a digital refractometer (Atago Co. Ltd., Tokyo, Japan). Titratable acidity (TA) was determined according to AOAC (Association of Official Agricultural Chemists) [20]. The maturity index was expressed as the ratio between SSC and TA [21], and apple juice $\mathrm{pH}$ was measured with a Crison $\mathrm{pH}$ meter.

For each sample, soluble solids, titratable acidity, and $\mathrm{pH}$ were carried in quintuplets for each sample on the juice obtained by nine apple slices, taken from three replicated treatments.

Surface colour was measured in control and treated samples using a Chroma Meter CR-400 reflectance colorimeter (Minolta Italia, Milano, Italy). In order to verify the effect on enzymatic browning, colour was monitored just after treatment and every hour up to the following $4 \mathrm{~h}$ on six slices for sampling.

The remaining 30 apple slices (45 in total; $15 \times$ treatment $\times$ three repetitions) for each treatment condition were immediately freeze-dried and used for the phenolic and antioxidant analysis.

\subsection{Polyphenolic Content by HPLC}

- Polyphenolic extract preparation

Freeze-dried apple powder $(250 \mathrm{mg})$ was weighed into an eppendorf tube. A total of $1.5 \mathrm{~mL}$ of $60 \%$ of aqueous methanol with $1 \%(v / v)$ of formic acid was added, and the suspension was vortexed vigorously for $2 \mathrm{~min}$. Tubes were left $60 \mathrm{~min}$ in a sonic bath. The extract was centrifuged for $20 \mathrm{~min}$ $(20.878 \times g)$, and supernatant was collected at $4{ }^{\circ} \mathrm{C}$ and transferred to a vial before the injection into the high-performance liquid chromatography (HPLC) system.

- High-performance liquid chromatography and mass spectrometry analysis

Before analysis, $20 \mu \mathrm{L}$ of each internal standard was added to the samples (genistein: $580 \mu \mathrm{g} / \mathrm{mL}$; genistin: $380 \mu \mathrm{g} / \mathrm{mL}$ ).

HPLC separations were carried out by means of a SUNSHELL C18 (2.1 i.d. $\times 100 \mathrm{~mm})$ column, with a $2.6 \mu \mathrm{m}$ particle size with the mobile phase, pumped at a flow-rate of $0.3 \mathrm{~mL} / \mathrm{min}$, and consisting 
of a mixture of acidified acetonitrile (0.1\% formic acid) (solvent $\mathrm{A}$ ) and $0.1 \%$ aqueous formic acid (solvent B). Following 0-2 min, 2\% B; 2-13 min, 2\% to 30\% B; $13-20 \mathrm{~min}, 30 \%$ to $80 \%$ B; $20-22 \mathrm{~min}$, $80 \%$ to $2 \% \mathrm{~B} ; 22-30 \mathrm{~min}, 2 \%$ isocratic; this step was followed by the washing and reconditioning of the column.

The identity of the phenolic compounds was confirmed using a triple quadrupole mass spectrometer (Thermo Scientific, TSQ Vantage) with a heated electrospray ionization (H-ESI II) operating in the negative ionization mode. The capillary temperature was $270{ }^{\circ} \mathrm{C}$; the sheath gas and auxiliary gas were 40 and 5 arbitrary units, respectively; and the source voltage was $3 \mathrm{kV}$. The vaporizer temperature $200{ }^{\circ} \mathrm{C}$ argon was used for MS experiments with a collision pressure of 1.0.

For the identification of phenolic compounds, a full-scan analysis was performed with scanning from $m / z 100$ to 950, while a product ion scan experiment was applied for ions not fully identified in the previous method. Identification was performed by comparing the mass spectra with data in literature, and the identification was confirmed by using pure standards of the components whenever possible.

Quantification was achieved in Selected Ion Monitoring mode according to the concentrations of the corresponding internal standard, respectively; that is, genistin for glucoside and genistein for aglicone.

\subsection{In Vitro Antioxidant Activity and Total Phenolics Index}

The antioxidant activity and total phenolics index of apple samples were assessed by different in vitro microplate assays, using the methods previously reported [11]. The antioxidant activity was performed by using the ABTS (2,2'-azino-bis(3-ethylbenzothiazoline-6-sulphonic acid)), DPPH (2,2-diphenyl-1-picrilhydrazyl), and FRAP (ferric reducing antioxidant power) methods. The total polyphenols content was quantified on both amphiphilic and hydrophilic extracts by the Folin-Ciocalteu phenol reagent.

\subsection{Statistical Analysis}

Data are expressed as mean values \pm SD for the indicated number of independent determinations.

A one-way ANOVA test was carried out to test the significance of the effects of treatment time on all the tested parameters. Significant differences $(p<0.05)$ between mean values were tested by the LSD test.

Statistical analyses were carried out using the STATISTICA software for Windows (StatsoftTM, Tulsa, OK, USA).

\section{Results and Discussion}

\subsection{Chemical Parameters}

Chemical parameters of apple samples are reported in Table 1. Water content and maturity index (SSC/TA) were not affected by the treatment and did not show any significant difference compared to the control sample at all treatment times.

Table 1. Physico-chemical parameters of Pink Lady apples, as affected by plasma treatment time.

\begin{tabular}{ccccc}
\hline & \multicolumn{4}{c}{ Time (min) } \\
\cline { 2 - 5 } & $\mathbf{0}$ & $\mathbf{1 0}$ & $\mathbf{2 0}$ & $\mathbf{3 0}$ \\
\hline Water content (\%) & $83.73 \mathrm{a}$ & $83.53 \mathrm{a}$ & $84.84 \mathrm{a}$ & $83.63 \mathrm{a}$ \\
MI (SSC/TA) & $34.88 \mathrm{a}$ & $33.08 \mathrm{a}$ & $37.68 \mathrm{a}$ & $34.54 \mathrm{a}$ \\
$\mathrm{pH}$ & $3.73 \mathrm{a}$ & $3.64 \mathrm{~b}$ & $3.56 \mathrm{~b}$ & $3.65 \mathrm{~b}$ \\
$\mathrm{~L}^{*}(4 \mathrm{~h})$ & $77.89 \mathrm{a}$ & $76.93 \mathrm{a}$ & $76.87 \mathrm{a}$ & $79.48 \mathrm{~b}$ \\
$\mathrm{a}^{*}(4 \mathrm{~h})$ & $0.59 \mathrm{a}$ & $0.08 \mathrm{a}$ & $-0.56 \mathrm{a}$ & $-2.49 \mathrm{~b}$ \\
$\mathrm{~b}^{*}(4 \mathrm{~h})$ & $26.75 \mathrm{a}$ & $27.03 \mathrm{a}$ & $27.16 \mathrm{a}$ & $24.54 \mathrm{~b}$ \\
\hline
\end{tabular}

Values followed by different letters within the same row are significantly different at a $p<0.05$ level. 
Slight acidification was observed upon plasma exposure, independently of treatment time. While some other quality parameters, such as color and texture, have been studied in a wide range of food products, the impact of plasma on product $\mathrm{pH}$ has not been investigated often. No differences were observed by Gurol et al. [22] in milk or other model liquid systems treated with argon plasma. However, Satoh et al. [23] found a strong decrease of PBS buffer $\mathrm{pH}$ from 7.3 to 3-4, as well as an increase of conductivity as a consequence of pulsed plasma exposure. Slight acidification was observed also in pork loins treated with a DBD device, with helium and oxygen as the working gas [24]. The authors suggested that those changes were due to the dissolution of acidogenic molecules, such as nitrogen oxides, generally generated in plasma discharges in the food system.

Color was measured four hours after treatment in order to evaluate a possible effect on the browning of fresh-cut apples. No differences were observed up to $20 \mathrm{~min}$ of treatment; however, samples exposed for 30 min were characterized by higher $L^{*}$ values and lower $a^{*}$ and $b^{*}$ values compared to the untreated sample.

These results confirm those obtained in a previous study of plasma effects on browning inhibition [25], where with the same experimental conditions, a reduction in browning was observed after $30 \mathrm{~min}$ of treatment by image analysis. In the same study, an inhibition of polyphenoloxidase (PPO) activity proportional to treatment time up to $57 \%$ after a 30 min treatment was reported.

Reduction of enzymatic activity upon plasma exposure has been observed in various studies [26,27], and has been attributed to the oxidation of the reactive side-chain of the amino acids by plasma radicals, particularly $\mathrm{OH}, \mathrm{O} 2-; \mathrm{HOO}$ and $\mathrm{NO}$, that promote a change in the secondary protein structure and the modification of some amino acids' side-chains of the enzyme [28]. In particular, Surowsky et al. [25] found a variation in the relative amounts of $\alpha$-helix structures and $\beta$-sheet content upon plasma exposure which was strongly correlated to the loss of enzymatic activity. Generally, the inhibitory effect is dependent on the type of enzyme considered and on the matrix effect [29].

\subsection{Phenolic Content}

The phenolic content of apples was measured by HPLC-MS/MS analysis, and the content of each detected phenolic is reported in Table 2. The phenolic content of Pink Lady apples was $2.14 \mathrm{mmol} \mathrm{kg}^{-1}$ f.w. (144 $\mathrm{mg} \mathrm{kg}^{-1}$ f.w.), which is in agreement with the range that was reported in previous studies $[11,30]$. In order to verify whether the DBD plasma treatment carried out in the experimental conditions of this study could have determined a significant decrease of polyphenols, the product was over-treated for $120(60+60)$ min of processing, whereby a significant decrease (17\% ca.) of total phenolic was observed.

At the investigated treatment time suitable for fresh-cut apple stabilization [25], the treatment was found to significantly affect the total phenolic content of apples, with a significant increase $(21 \% \mathrm{ca}$.) after $10(5+5)$ min of processing, which reduced slightly in the $20(10+10)$ min treated sample, and after $30(15+15) \mathrm{min}$, reached values not significantly different from those of raw apples (Table 2). 
Table 2. Content of phenolics ( $\mu \mathrm{mol} \mathrm{kg} \mathrm{kg}^{-1}$ f.w.) of Pink Lady apples, as affected by plasma treatment time.

\begin{tabular}{|c|c|c|c|c|c|c|}
\hline & \multirow{2}{*}{ Compound } & \multicolumn{5}{|c|}{ Time (min) } \\
\hline & & 0 & 10 & 20 & 30 & 120 \\
\hline \multirow[t]{10}{*}{ Flavan-3-ols } & Catechin & $46.6 \mathrm{ab}$ & $40.5 b c$ & $48.8 \mathrm{a}$ & $36.9 \mathrm{c}$ & $26.8 \mathrm{~d}$ \\
\hline & Epicatechin & $365 a$ & $353 \mathrm{ab}$ & $398 \mathrm{a}$ & $303 b$ & $229 \mathrm{c}$ \\
\hline & Procyanidin dimer B1 & $40.1 \mathrm{a}$ & $37.8 \mathrm{a}$ & $39.0 \mathrm{a}$ & $31.2 \mathrm{~b}$ & $17.8 \mathrm{c}$ \\
\hline & Procyanidin dimer B2 & $138 \mathrm{a}$ & $135 \mathrm{ab}$ & $141 \mathrm{a}$ & $113 b$ & $70.9 \mathrm{c}$ \\
\hline & Procyanidin dimer B4 & $9.61 \mathrm{a}$ & $9.86 \mathrm{a}$ & $9.40 \mathrm{ab}$ & $7.63 b$ & $4.63 \mathrm{c}$ \\
\hline & Procyanidin B trimer & $8.62 \mathrm{a}$ & $8.14 a$ & $7.81 \mathrm{a}$ & $6.57 \mathrm{~b}$ & $3.53 c$ \\
\hline & Procyanidin B trimer 2 & $15.3 \mathrm{a}$ & $14.8 \mathrm{a}$ & $14.4 \mathrm{a}$ & $11.4 \mathrm{~b}$ & $7.01 \mathrm{c}$ \\
\hline & Procyanidin B trimer 3 & $49.6 \mathrm{a}$ & $49.0 \mathrm{a}$ & $46.3 a$ & $37.0 \mathrm{~b}$ & $20.3 c$ \\
\hline & Procyanidin B trimer 4 & $7.00 \mathrm{a}$ & $7.30 \mathrm{a}$ & $6.50 \mathrm{ab}$ & $5.40 \mathrm{~b}$ & $2.68 \mathrm{c}$ \\
\hline & Procyanidin B trimer 5 & $0.39 \mathrm{~b}$ & $15.05 \mathrm{a}$ & $13.52 b$ & $0.14 \mathrm{~b}$ & $0.05 \mathrm{~b}$ \\
\hline \multirow[t]{5}{*}{ Hydroxycinnamic acids } & Caffeic acid & $0.96 a$ & $0.55 \mathrm{~b}$ & $1.13 \mathrm{a}$ & $0.98 \mathrm{a}$ & $1.02 \mathrm{a}$ \\
\hline & Caffeoylquinic acid isomer 1 & $292 b$ & $384 a$ & $291 b$ & $263 b c$ & $238 \mathrm{c}$ \\
\hline & Caffeoylquinic acid isomer 2 & $613 b c$ & $832 a$ & $685 b$ & $620 \mathrm{bc}$ & $591 \mathrm{c}$ \\
\hline & 4-Coumaroyl quinic acid & $91.9 \mathrm{a}$ & $99.2 \mathrm{a}$ & $97.7 \mathrm{a}$ & $77.9 \mathrm{~b}$ & $80.8 b$ \\
\hline & Coumaroyl quinic acid & $247 \mathrm{~b}$ & $302 \mathrm{a}$ & $268 \mathrm{ab}$ & $257 a$ & $283 a b$ \\
\hline \multirow[t]{2}{*}{ Dihydrochalcones } & $\begin{array}{l}\text { Phloretin-2'-O-(2"'-O-xylosyl) } \\
\text { glucoside }\end{array}$ & $145 b$ & $196 a$ & $187 \mathrm{a}$ & $197 \mathrm{a}$ & $139 b$ \\
\hline & Phloridzin & $35.7 \mathrm{c}$ & $49.9 \mathrm{bc}$ & $54.5 b$ & $81.2 \mathrm{a}$ & $25.8 \mathrm{c}$ \\
\hline \multirow[t]{5}{*}{ Flavonols } & Myricetin rhamnoside & $2.89 \mathrm{bc}$ & $4.95 \mathrm{a}$ & $3.64 \mathrm{~b}$ & $2.94 \mathrm{bc}$ & $2.30 \mathrm{c}$ \\
\hline & Ouercetin & $2.77 \mathrm{bc}$ & $4.22 \mathrm{a}$ & $3.49 \mathrm{ab}$ & $3.55 \mathrm{a}$ & $2.33 \mathrm{c}$ \\
\hline & Quercetin-O-glucoside & $2.90 \mathrm{~b}$ & $6.22 \mathrm{a}$ & $3.70 \mathrm{~b}$ & $2.97 \mathrm{~b}$ & $2.28 \mathrm{~b}$ \\
\hline & Quercetin-O-rhamnoside & $27.0 \mathrm{~b}$ & $37.2 \mathrm{a}$ & $32.8 \mathrm{ab}$ & $33.2 \mathrm{a}$ & $24.2 b$ \\
\hline & Rutin & $0.13 \mathrm{a}$ & $0.06 \mathrm{ab}$ & $0.14 \mathrm{a}$ & $0.05 b$ & $0.00 \mathrm{c}$ \\
\hline Total phenolics & & $2142 b$ & $2588 a$ & $2352 \mathrm{ab}$ & $2092 b$ & $1774 \mathrm{c}$ \\
\hline
\end{tabular}

Values followed by different letters within the same row are significantly different at a $p<0.05$ level.

Specifically, the initial phenolic increase after $10 \mathrm{~min}$ of processing was mainly due to a significant increase of procyanidin B trimer, flavonols, hydroxycinnamic acids, and phloretin xylosyl glucoside.

The increase of procyanidin B trimer was the most outstanding in relative terms and corresponded, in molar terms, to a reduction of catechin, epicatechin, and dimers B1 and B2, suggesting the occurrence of polymerization reaction. When calculated as a percentage of total procyanidins, the content of trimeric procyanidins increased, while those of dimeric and monomeric procyanidins decreased. According to Nicoli et al. [31], the formation of procyanidins upon catechins polymerization occurs in apples due to both enzymatic and chemical oxidation reactions; the latter could easily take place during plasma treatment due to the action of radical species and the availability of oxygen in the atmosphere. Procyanidins with high molecular weight (from tetramers to decamers) where not found in this study, while oligomers up to dodecamers have been previously observed in Red Delicious apples. This difference may be due to the different extraction procedure used for the HPLC-MS/MS analysis. Specifically, in the present study, methanol:water was used for the extraction of polyphenols from the freeze-dried samples, while the compounds with higher molecular weight were generally extracted using acetone:water mixtures [32].

The increase of trimer concentration could also have other explanations, since the extraction of procyanidins in apples could be favored by the activity of some carbohydrate-hydrolyzing enzymes, such as pectinase, cellulase, hemicellulase, and glucanase, which help the release of polyphenols complexed with cell walls [33-35], which are mainly catechin and procyanidins. Indeed, polyphenols, which are mainly located in vacuoles, can form complexes with polysaccharides in the cell wall through non-covalent binding upon decompartmentalization [36].

As 10 min of cold plasma processing in the same experimental conditions of this study were found to slightly affect (12\% ca. reduction) the enzymatic activity present in apples [25], it is not clear whether other naturally occurring apple enzymes (e.g., pectinases) are likely to exert their hydrolytic activity within this period of time. In this study, no increase in catechin and dimeric procyanidin was observed 
after 10 min of treatment; however, this fact does not suggest the occurrence of any enzyme-mediated release of procyanidins, because the content of $\mathrm{B} 2$ dimeric procyanidin has to increase as a consequence of enzymatic hydrolysis [35,37].

However, since cell walls' polysaccharides form a higher number of complexes with procyanidins that have high molecular weight rather than those with low molecular weight [38], the increase of trimeric procyanidins $(17 \%)$, which could be caused by a polymerization reaction upon oxidation, could also have been influenced by the enzymatic-mediated release from the complexes of cell walls' polyphenols after $10 \mathrm{~min}$ of processing.

Chlorogenic acid (caffeoylquinic acids isomers) and phloridzin showed a 30 and $40 \%$ increase of their initial concentration after $10 \mathrm{~min}$ of cold plasma treatment. The increase of hydroxycinnamic acids and chalcones in plant tissues is associated with the wounding response which induces an increase in the content of phenolic compounds, likely due to their biosynthesis through the phenyl-propanoid pathway as a plant defense mechanism [39,40]. Selected antifungal polyphenols, such as chlorogenic acid, isochlorogenic acid, chalcones, and especially phloridzin, could be synthesized after an elicited increased activity of the key enzymes (phenylalanine ammonia lyase and chalcone synthase) of the phenyl-propanoid biosynthetic pathway $[39,41]$. The increase of these compounds may also partly be due to the activity of hydrolases, although according to some previous studies [32,34], a dramatic increase of caffeic acid should also be observed, which is contrary to our results. On the other hand, the increase of phloridzin and rutin that we found are in agreement with enzyme-assisted hydrolysis [35].

Moreover, the increase in quercetin and quercetin glucoside observed after $10 \mathrm{~min}$ of plasma treatment could be a consequence of hydrolysis of the cell wall [37]. In general, a 40 to $110 \%$ increase of polyphenols conjugated to the monomeric constituents of the cell walls, among which rhamnosides and xylosides in particular was observed (Table 2); however, these types of polyphenols are not considered as constituents of the cell walls [42].

With some exceptions, at treatment times longer than $10 \mathrm{~min}$, all the polyphenols showed a progressive reduction.

When calculated according to the percentage of total procyanidins, trimer reduction was higher than that of monomers and dimers. As discussed previously, in addition to oxidation and polymerization, catechin and procyanidins could also undergo binding to the cell walls, and oxidized procyanidins and procyanidins with high molecular weight could bind better than the reduced and monomeric compounds, respectively [38].

Similar results were observed by Rodrigues et al. [43] using an indirect N2 plasma on cashew apple juice. At the lowest flow rate, the authors found an increase of vitamin $C$ and polyphenols, attributed to the activation of antioxidant compounds in response to the oxidative damage produced by the reactive species from the plasma. However, increasing the flow rate led to a decrease of the bioactive compound content and of the antioxidant activity.

The total phenolic index (TPI) was measured both on the amphiphilic and on the hydrophilic fraction, and obtained values were 12.6 and $0.8 \mu \mathrm{mol} \mathrm{g}{ }^{-1}$ d.w., respectively, confirming that apples are very low in water-soluble polyphenols and ascorbic acid.

The amphiphilic fraction was significantly affected by plasma exposure with a significant increase (+8.5\% ca.) after $10 \mathrm{~min}$ of processing, followed by a progressive decrease with the increasing of processing time to reach significantly lower values (about $-9 \%$ ) than those of raw apples after $30 \mathrm{~min}$, and of about $-35 \%$ in the sample over-treated for $120 \mathrm{~min}$ (Table 2).

The discrepancies found between the spectrophotometric determination and the HPLC-MS/MS analysis were already observed in a previous study [11] and was related to the different classes of polyphenols involved, particularly to their reducing power. 


\subsection{Antioxidant Activity}

As previously reported in different studies, the evaluation of antioxidant activity through a combination of different in vitro assays in a multimodal approach is very useful to understand the effect of different treatments on fruit and vegetable tissues.

The data on antioxidant activity measured with different methods are reported in Table 3.

Table 3. Total phenolic content (TPI) and antioxidant activity ( $\mu \mathrm{mol} \mathrm{kg}{ }^{-1}$ f.w.) of Pink Lady apples, as affected by plasma treatment time.

\begin{tabular}{ccccccc}
\hline & \multirow{2}{*}{ Extract } & \multicolumn{5}{c}{ Time (min) } \\
\cline { 3 - 7 } & & $\mathbf{0}$ & $\mathbf{1 0}$ & $\mathbf{2 0}$ & $\mathbf{3 0}$ & $\mathbf{1 2 0}$ \\
\hline TPI $^{*}$ & amphiphilic & $12,633 \mathrm{~b}$ & $13,702 \mathrm{a}$ & $12,460 \mathrm{~b}$ & $11,383 \mathrm{c}$ & $8207 \mathrm{~d}$ \\
TPI $^{*}$ & hydrophilic & $855 \mathrm{~b}$ & $917 \mathrm{ab}$ & $981 \mathrm{ab}$ & $1050 \mathrm{a}$ & $623 \mathrm{c}$ \\
TPI $^{*}$ & total & $13,484 \mathrm{~b}$ & $14,622 \mathrm{a}$ & $13,357 \mathrm{~b}$ & $12,242 \mathrm{c}$ & $8790 \mathrm{~d}$ \\
ABTS $^{* *}$ & amphiphilic & $14,265 \mathrm{~b}$ & $15,076 \mathrm{a}$ & $14,734 \mathrm{ab}$ & $13,526 \mathrm{~b}$ & $10,098 \mathrm{c}$ \\
ABTS $^{* *}$ & hydrophilic & $855 \mathrm{a}$ & $644 \mathrm{~b}$ & $840 \mathrm{ab}$ & $686 \mathrm{~b}$ & $803 \mathrm{ab}$ \\
ABTS $^{* *}$ & total & $15,120 \mathrm{ab}$ & $15,720 \mathrm{a}$ & $15,574 \mathrm{a}$ & $14,212 \mathrm{~b}$ & $10,900 \mathrm{c}$ \\
DPPH $^{* *}$ & total & $22,543 \mathrm{a}$ & $23,008 \mathrm{a}$ & $21,311 \mathrm{a}$ & $21,868 \mathrm{a}$ & $16,608 \mathrm{~b}$ \\
FRAP *** & total & $26,900 \mathrm{~b}$ & $30,123 \mathrm{a}$ & $27,781 \mathrm{~b}$ & $25,913 \mathrm{~b}$ & $17,024 \mathrm{c}$ \\
\hline
\end{tabular}

Values followed by different letters within the same row are significantly different at a $p<0.05$ level. ${ }^{*}\left(\mu \mathrm{mol} \mathrm{GAE} \mathrm{kg}{ }^{-1}\right.$ f.w.), ${ }^{* *}$ ( $\mu \mathrm{mol} \mathrm{TE} \mathrm{kg}{ }^{-1}$ f.w.), ${ }^{* * *}\left(\mu \mathrm{mol} \mathrm{Fe}{ }^{2+} \mathrm{kg}^{-1}\right.$ f.w.).

The radical scavenging activity (RSA) was measured through ABTS and DPPH assays. The results of the ABTS assays were significantly affected by plasma exposure. In particular, an initial increase of about $5 \%$ for the total activity was observed, followed by a progressive decrease with the increasing of processing time, to reach values lower than those of raw apples (-28\%) after $120 \mathrm{~min}$ of exposure time (Table 3), due mainly to an effect on the hydrophilic fraction.

The RSA measured through the DPPH assay showed fewer changes, confirming its lower sensitivity compared to the ABTS assay already observed in previous studies [11,12].

The FRAP and TPI assays were used to evaluate the reducing power of extracts that generally showed a similar trend, with an initial increase followed by a final decrease with increasing plasma exposure time.

The initial increase was of about $8.5 \%$ for TPI and $11 \%$ for FRAP, while final values after $120 \mathrm{~min}$ of treatment were -34 and $-37 \%$, respectively.

The initial increase of antioxidant activity after $10 \mathrm{~min}$ of treatment could be ascribed to the increase of selected polyphenols as a response to wounding. Several studies have been performed regarding the effect of wounding response on antioxidant activity [40,44-46] and the results observed in this study are similar to those reported by Heredia and Cisneros-Zevallos [40]. On the other hand, the initial increase of antioxidant activity after $10 \mathrm{~min}$ of treatment could be also due to catechins oxidation, which causes the formation of procyanidins (e.g., trimers) which have higher antioxidant activity than the former compounds [31,47]. An initial increase of antioxidant activity followed by its reduction was also observed during the oxidation of processed apple products by Sacchetti et al. [48], who observed that this increase depended on both the activity of oxidases and the concentration of polyphenols.

\section{Conclusions}

The effects of plasma treatment on physico-chemical parameters was mainly observed as a slight acidification of the tissue, and as a reduction of browning after longer exposure time (30 min), which was most likely due to enzymatic activity inhibition.

As a consequence of catechin polymerization products and of the increase in hydroxycinnamic acids and chalcones, the phenolic profile of fresh-cut apples was significantly affected by $10 \mathrm{~min}$ of treatment, both in quantitative (approximately a $20 \%$ increase) and qualitative terms. 
After 30 min of treatment, when the effect of plasma on enzymatic browning inhibition was significant, flavan-3-oils content was lower compared to the untreated apples, while dihydrochalcones and flavonols showed a slight increase.

As expected, considering its strict connection with the amount of polyphenols, antioxidant activity evaluated by different in vitro methods followed a similar trend, increasing after $10 \mathrm{~min}$ of processing. The DPPH showed lower sensibility compared with ABTS assays, while FRAP showed similar values to the TPI assay.

Results highlighted how plasma exposure promotes a metabolic response of the fresh tissue that can noticeably influence the quality of the final product. Hence, it is of paramount importance to carefully select the exposure time in order to minimize the loss of nutritional properties.

Author Contributions: Conceptualization: S.T. and P.R., methodology: I.R. and G.S., formal analysis: S.T. and I.R., supervision: L.R., data curation: S.T. and I.R., writing of original draft: S.T. and G.S., manuscript review and editing: P.R. and F.R.

Funding: This research was funded by the INNOFRUVE project (grant number (CUP) J12F16000020009), co-funded by the Emilia-Romagna Region through the POR FESR 2014-2020 funds (European Regional Development Fund).

Conflicts of Interest: The authors declare no conflict of interest.

\section{References}

1. Weltmann, K.D.; Kindel, E.; von Woedtke, T.; Hähnel, M.; Stieber, M.; Brandenburg, R. Atmospheric-pressure plasma sources: Prospective tools for plasma medicine. Pure Appl. Chem. 2010, 82, 1223-1237. [CrossRef]

2. Fridman, G.; Friedman, G.; Gutsol, A.; Shekhter, A.B.; Vasilets, V.N.; Fridman, A. Applied plasma medicine. Plasma Process. Polym. 2008, 5, 503-533. [CrossRef]

3. Guo, J.; Huang, K.; Wang, J. Bactericidal effect of various non-thermal plasma agents and the influence of experimental conditions in microbial inactivation: A review. Food Control 2015, 5, 482-490. [CrossRef]

4. Misra, N.N.; Tiwari, B.K.; Raghavarao, K.S.M.S.; Cullen, P.J. Nonthermal plasma inactivation of food-borne pathogens. Food Eng. Rev. 2011, 3, 159-170. [CrossRef]

5. Hojnik, N.; Cvelbar, U.; Tavčar-Kalcher, G.; Walsh, J.L.; Križaj, I. Mycotoxin decontamination of food: Cold atmospheric pressure plasma versus "classic" decontamination. Toxins 2017, 9, 151. [CrossRef] [PubMed]

6. Lacombe, A.; Niemira, B.A.; Gurtler, J.B.; Sites, J.; Boyd, G.; Kingsley, D.H.; Li, X.; Chen, H. Nonthermal inactivation of norovirus surrogates on blueberries using atmospheric cold plasma. Food Microbiol. 2017, 63, 1-5. [CrossRef] [PubMed]

7. Keener, K.M.; Misra, N.N. Future of cold plasma in food processing. In Cold Plasma in Food and Agriculture; Elsevier: Amsterdam, The Netherlands, 2016; pp. 343-360, ISBN 978-0-12-801365-6.

8. Misra, N.N.; Pankaj, S.K.; Segat, A.; Ishikawa, K. Cold plasma interactions with enzymes in foods and model systems. Trends Food Sci. Technol. 2016, 55, 39-47. [CrossRef]

9. Grzegorzewski, F.; Rohn, S.; Kroh, L.W.; Geyer, M.; Schlüter, O. Surface morphology and chemical composition of lamb's lettuce (Valerianella locusta) after exposure to a low-pressure oxygen plasma. Food Chem. 2010, 122, 1145-1152. [CrossRef]

10. Grzegorzewski, F.; Ehlbeck, J.; Schlüter, O.; Kroh, L.W.; Rohn, S. Treating lamb's lettuce with a cold plasma-Influence of atmospheric pressure Ar plasma immanent species on the phenolic profile of Valerianella locusta. LWT-Food Sci. Technol. 2011, 44, 2285-2289. [CrossRef]

11. Ramazzina, I.; Tappi, S.; Rocculi, P.; Sacchetti, G.; Berardinelli, A.; Marseglia, A.; Rizzi, F. Effect of cold plasma treatment on the functional properties of fresh-cut apples. J. Agric. Food Chem. 2016, 64, 8010-8018. [CrossRef] [PubMed]

12. Ramazzina, I.; Berardinelli, A.; Rizzi, F.; Tappi, S.; Ragni, L.; Sacchetti, G.; Rocculi, P. Effect of cold plasma treatment on physico-chemical parameters and antioxidant activity of minimally processed kiwifruit. Postharvest Biol. Technol. 2015, 107, 55-65. [CrossRef]

13. Wang, R.X.; Nian, W.F.; Wu, H.Y.; Feng, H.Q.; Zhang, K.; Zhang, J.; Zhu, W.D.; Becker, K.H.; Fang, J. Atmospheric-pressure cold plasma treatment of contaminated fresh fruit and vegetable slices: Inactivation and physiochemical. Eur. Phys. J. D 2012, 66, 276. [CrossRef] 
14. Kovačević, D.B.; Putnik, P.; Dragović-Uzelac, V.; Pedisić, S.; Režek Jambrak, A.; Herceg, Z. Effects of cold atmospheric gas phase plasma on anthocyanins and color in pomegranate juice. Food Chem. 2016, 190, 317-323. [CrossRef] [PubMed]

15. Kovačević, D.B.; Kljusurić, J.G.; Putnik, P.; Vukušić, T.; Herceg, Z.; Dragović-Uzelac, V. Stability of polyphenols in chokeberry juice treated with gas phase plasma. Food Chem. 2016, 212, 323-331. [CrossRef] [PubMed]

16. Garofuli, I.E.; Jambrak, A.R.; Milošević, S.; Dragović-Uzelac, V.; Zorić, Z.; Herceg, Z. The effect of gas phase plasma treatment on the anthocyanin and phenolic acid content of sour cherry Marasca (Prunus cerasu s var. Marasca) juice. LWT-Food Sci. Technol. 2015, 62, 894-900. [CrossRef]

17. Bußler, S.; Herppich, W.B.; Neugart, S.; Schreiner, M.; Ehlbeck, J.; Rohn, S.; Schlüter, O. Impact of cold atmospheric pressure plasma on physiology and $\mathrm{fl}$ avonol glycoside pro fi le of peas (Pisum sativum 'Salamanca'). FRIN 2015, 76, 132-141. [CrossRef]

18. Ragni, L.; Berardinelli, A.; Vannini, L.; Montanari, C.; Sirri, F.; Guerzoni, M.E.; Guarnieri, A. Non-thermal atmospheric gas plasma device for surface decontamination of shell eggs. J. Food Eng. 2010, 100, 125-132. [CrossRef]

19. AOAC International. Official Methods of Analysis (OMA) of AOAC International, 17th ed.; AOAC International: Gaithersburg, MD, USA, 2002.

20. AOAC International. Official Methods of Analysis (OMA) of AOAC International; Method number: 942.15; AOAC International: Gaithersburg, MD, USA, 2000; Available online: http: / / www.eoma.aoac.org/ (accessed on 18 July 2017).

21. Sweeney, J.P.; Chapman, V.J.; Hepner, P.A. Sugar, acid, and flavor in fresh fruits. J. Am. Diet. Assoc. 1970, 57, 432-435. [PubMed]

22. Gurol, C.; Ekinci, F.Y.; Aslan, N.; Korachi, M. Low temperature plasma for decontamination of E. coli in milk. Int. J. Food Microbiol. 2012, 157, 1-5. [CrossRef] [PubMed]

23. Satoh, K.; MacGregor, S.J.; Anderson, J.G.; Woolsey, G.A.; Fouracre, R.A. Pulsed-plasma disinfection of water containing Escherichia col. Jpn. J. Appl. Phys. 2007, 46, 1137. [CrossRef]

24. Kim, H.J.; Yong, H.I.; Park, S.; Choe, W.; Jo, C. Effects of dielectric barrier discharge plasma on pathogen inactivation and the physicochemical and sensory characteristics of pork loin. Curr. Appl. Phys. 2013, 13, 1420-1425. [CrossRef]

25. Tappi, S.; Berardinelli, A.; Ragni, L.; Dalla Rosa, M.; Guarnieri, A.; Rocculi, P. Atmospheric gas plasma treatment of fresh-cut apples. Innov. Food Sci. Emerg. Technol. 2014, 21, 114-122. [CrossRef]

26. Pankaj, S.K.; Misra, N.N.; Cullen, P.J. Kinetics of tomato peroxidase inactivation by atmospheric pressure cold plasma based on dielectric barrier discharge. Innov. Food Sci. Emerg. Technol. 2013, 19, 153-157. [CrossRef]

27. Surowsky, B.; Fischer, A.; Schlueter, O.; Knorr, D. Cold plasma effects on enzyme activity in a model food system. Innov. Food Sci. Emerg. Technol. 2013, 19, 146-152. [CrossRef]

28. Takai, E.; Kitano, K.; Kuwabara, J.; Shiraki, K. Protein inactivation by low-temperature atmospheric pressure plasma in aqueous solution. Plasma Process. Polym. 2012, 9, 77-82. [CrossRef]

29. Tappi, S.; Gozzi, G.; Vannini, L.; Berardinelli, A.; Romani, S.; Ragni, L.; Rocculi, P. Cold plasma treatment for fresh-cut melon stabilization. Innov. Food Sci. Emerg. Technol. 2016, 33, 225-233. [CrossRef]

30. Veberic, R.; Trobec, M.; Herbinger, K.; Hofer, M.; Grill, D.; Stampar, F. Phenolic compounds in some apple (Malus domestica Borkh) cultivars of organic and integrated production. J. Sci. Food Agric. 2005, 85, 1687-1694. [CrossRef]

31. Nicoli, M.C.; Calligaris, S.; Manzocco, L. Effect of enzymatic and chemical oxidation on the antioxidant capacity of catechin model system and apple derivatives. J. Agric. Food Chem. 2000, 48, 4576-4580. [CrossRef] [PubMed]

32. Lazarus, S.A.; Adamson, G.E.; Hammerstone, J.F.; Schmitz, H.H. High-performance liquid chromatography/mass spectrometry analysis of proanthocyanidins in foods and beverages. J. Agric. Food Chem. 1999, 47, 3693-3701. [CrossRef] [PubMed]

33. Landbo, A.K.; Meyer, A.S. Enzyme-assisted extraction of antioxidative phenols from black currant juice press residues (Ribes nigrum). J. Agric. Food Chem. 2002, 49, 3169-3177. [CrossRef]

34. Sørensen, H.R.; Pedersen, S.; Anders, V.N.; Meyer, A.S. Efficiencies of designed enzyme combinations in releasing arabinose and xylose from wheat arabinoxylan in an industrial ethanol fermentation residue. Enzyme Microb. Technol. 2005, 36, 773-784. [CrossRef] 
35. Pinelo, M.; Zornoza, B.; Meyer, A.S. Selective release of phenols from apple skin: Mass transfer kinetics during solvent and enzyme-assisted extraction. Sep. Purif. Technol. 2008, 63, 620-627. [CrossRef]

36. Jiménez-Escrig, A. Dietary fiber and its polyhenol cotravelers in healthy eating: Seeking the key component in apple fruit. In Polysaccharides: Natural Fibers in Food and Nutrition; Benkeblia, N., Ed.; CRC Press: Boca Raton, FL, USA, 2014; pp. 31-43.

37. Zheng, H.Z.; Hwang, I.W.; Chung, S.K. Enhancing polyphenol extraction from unripe apples by carbohydrate-hydrolyzing enzymes. J. Zhejiang Univ. Sci. B 2009, 10, 912-919. [CrossRef] [PubMed]

38. Poncet-Legrand, C.; Cabane, B.; Bautista-Ortín, A.B.; Carrillo, S.; Fulcrand, H.; Pérez, J.; Vernhet, A. Tannin oxidation: Intra- versus intermolecular reactions. Biomacromolecules 2010, 11, 2376-2386. [CrossRef] [PubMed]

39. Uritani, I.; Asahi, T. Respiration and related metabolic activity in wounded and infected tissues. In Metabolism and Respiration; Davies, D.D., Ed.; Academic Press: London, UK, 1980; pp. 463-486.

40. Heredia, J.B.; Cisneros-Zevallos, L. The effect of exogenous ethylene and methyl jasmonate on PAL activity; phenolic profiles and antioxidant capacity of carrots (Daucus carota) under different wounding intensities. Postharvest Biol. Technol. 2009, 51, 242-249. [CrossRef]

41. Lattanzio, V.; Lattanzio, V.M.T.; Cardinali, A. Role of phenolics in the resistance mechanisms of plants against fungal pathogens and insects. In Phytochemistry: Advances in Research; Imperato, F., Ed.; CRC Press: Boca Raton, FL, USA, 2006; pp. 31-43.

42. Pinelo, M.; Arnous, A.; Meyer, A.S. Upgrading of grape skins: Significance of plant cell-wall structural components and extraction techniques for phenol release. Trends Food Sci. Technol. 2006, 17, 579-590. [CrossRef]

43. Rodriguez, O.; Gomes, F.; Rodrigues, S.; Fernandes, F.A.N. Effect of indirect cold plasma treatment on cashew apple juice (Anacardium occidentale L.). LWT-Food Sci. Technol. 2017, 84, 457-463. [CrossRef]

44. Reyes, L.F.; Cisneros-Zevallos, L. Wounding stress increases the phenolic content and antioxidant capacity of purple-flesh potatoes (Solanum tuberosum L.). J. Agric. Food Chem. 2003, 5, 5296-5300. [CrossRef] [PubMed]

45. Reyes, L.F.; Villareal, E.; Cisneros-Zevallos, L. The increase in antioxidant capacity after wounding depends on the type of fruit or vegetable tissue. Food Chem. 2007, 101, 1254-1262. [CrossRef]

46. Kang, H.M.; Saltveit, M.E. Antioxidant capacity of lettuce leaf tissue increases after wounding. J. Agric. Food Chem. 2002, 50, 7536-7541. [CrossRef] [PubMed]

47. Di Mattia, C.; Martuscelli, M.; Sacchetti, G.; Scheirlinck, I.; Beheydt, B.; Mastrocola, D.; Pittia, P. Effect of fermentation and drying on procyanidins; antiradical activity and reducing properties of cocoa beans. Food Bioprocess Technol. 2013, 6, 3420-3432. [CrossRef]

48. Sacchetti, G.; Cocci, E.; Pinnavaia, G.G.; Mastrocola, D.; Dalla Rosa, M. Influence of processing and storage on the antioxidant activity of apple derivatives. Int. J. Food Sci. Technol. 2008, 43, 797-804. [CrossRef] 